Jpn. J. Oral Biol., $34: 274-279,1992$.

\title{
ORIGINAL
}

\section{Coronal cementum in the horse molar teeth}

\author{
Ichizoh Itoh and Hiroshi Saito \\ Department of Anatomy I. Ohu University School of Dentistry, \\ 31-1, Misumido, Tomita, Koriyama, Fukushima, 963 Japan
}

(Chief : Prof. Ichizoh Itoh)

[Accepted for publication : October 23, 1991]

Key words: coronal cementum/blood vessel/Sharpey's fiber/horse

\begin{abstract}
We examined the morphology of the horse coronal cementum, to study Sharpey's fibers and the blood vessels which become covered with coronal cementum. Histological studies were carried out on 12 functioning mandibular molar teeth of horses, immediately after slaughter. The arrangement of fundamental microstructures composed of collagen fibers (Sharpey's fibers) in coronal cementum and the distribution of blood vessels were studied by light and scanning electron microscopy, and light microscopy was used to observe the shape and distribution of the cemento-enamel junction. The molars were hypsodont, with long crowns and short roots. The apices were open as a result of continuous growth. Pericoronal cementum had a laminated structure, which may have been formed intermittently by cementoblasts in the periodontal ligament and at the eruption in the gingiva. The diameter of Sharpey's fibers at their insertion into cementum was about $50 \mu \mathrm{m}$. These fibers had diameters of $20-25 \mu \mathrm{m}$ in the deep layer and in the surrounding mineralized cementum. The vascular system was well developed in the concave portion on the buccal and lingual surfaces of the crown. Along the cemento-enamel junction relatively large blood vessels had entered the concave region, and along their way they gave off numerous branches in the coronal cementum. There were sinusoidlike vessels on a part of the enamel surface. The cemento-enamel junction in the horse crown had a characteristic structure: the enamel surface had a number of scallop-shaped resorption concavities, which provided firm connection between the cementum and the enamel.
\end{abstract}

\section{Introduction}

Cementum resembles bone and may be a type of bone tissue ${ }^{1)}$. Unlike alveolar bone, dentin, and enamel, there are few reports on the histological structure of cementum. Cementum coveres most of the tooth root in humans and carnivores, and fixes the tooth in the jaw bone. Cementum exposed to the oral cavity undergoes pathological changes caused by degeneration of cells and fibers on its surface, and by deep invasion of plaque-derived substances. In contrast herbivores have pericoronal cementum surrounding the crown and a large amount of cementum normally fills the occlusal groove. Thus, the structure of cementum may differ according to its location, and its histological characteristics may differ among animal species. This may be because, unlike enamel and dentin, cementum varies histologically and has no typical tissue structure from the time of its formation.

The existence of coronal cementum over the enamel of equine molars was reported by Havers $(1691)^{2)}$, Owen $(1845)^{3)}$ also examined the histology of the coronal cementum of the horse molar. Owen found an irregular junction between the enamel and the encapsulating vascular cementum.

Brunn (1891) ${ }^{4)}$ reported the presence of cartilage-like cementum in the crown. Muraki $(1958)^{5)}$ compared cementum among various mammals. Boyed et al. (1969) ${ }^{6)}$ described the 
surface morphology of cementum in various animal species. There have been histological studies of coronal cementum and embryological studies of cows ${ }^{5,7-10)}$, sheep ${ }^{5,11,12)}$, horses ${ }^{5,13,14)}$, and guinea pigs ${ }^{15-17)}$.

These studies have provided detailed information on the structure of coronal cementum. However, this is not true of Sharpey's fibers or of coronal cementum vasculature. The purpose of this investigation was to study Sharpey's fibers and blood vessels which become covered with coronal cementum in the molar teeth of horses.

\section{Materials and Methods}

Mandibular molars of four-years-old horses were used. Immediately after the horses were killed, the mandibles and molars were fixed in $10 \%$ neutral formalin for about 1 week. Some were divided into blocks containing one molar each, to prepare polished specimens. Others were cut into thin sections to prepare specimens for scanning electron microscopy, and then re-fixed for 24 hours.

Each block was dehydrated with a series of ethanol solutions, embedded in epoxy resin (Epoluck), polished, and after contact microradiography, was studied by light microscopy.

The specimens for scanning electron microscopy were fractured, and some were immersed in a $5 \%$ sodium hypochlorite $(\mathrm{NaOCl})$ solution for 40 minutes to remove organic substances. After dehydration with ethanol, substitution with isoamyl acetate, critical point drying, and gold vacuum evaporation, the surface of coronal cementum and the fractured surface were observed with Hitachi S-450 and HSM-2B scanning electron microscopes.

\section{Results}

Figure 1 shows a continuous growth root with its apex open. During the lifetime of the horse, attrition continues and this loss is compensated for by longitudinal growth over a long period of time and by continuous eruption.

Cross sections at a site near the cuspal apex showed that the spaces among the occlusal columns were filled with cementum and that

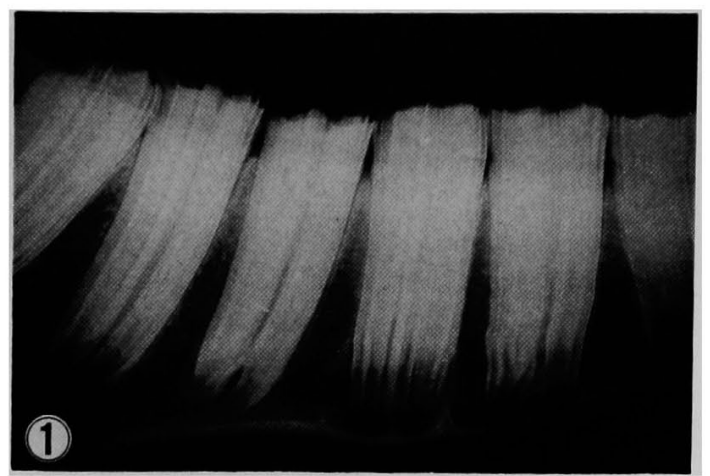

Fig. 1 Radiograph of a horse mandible showing the hypsodont nature of the molar teeth.

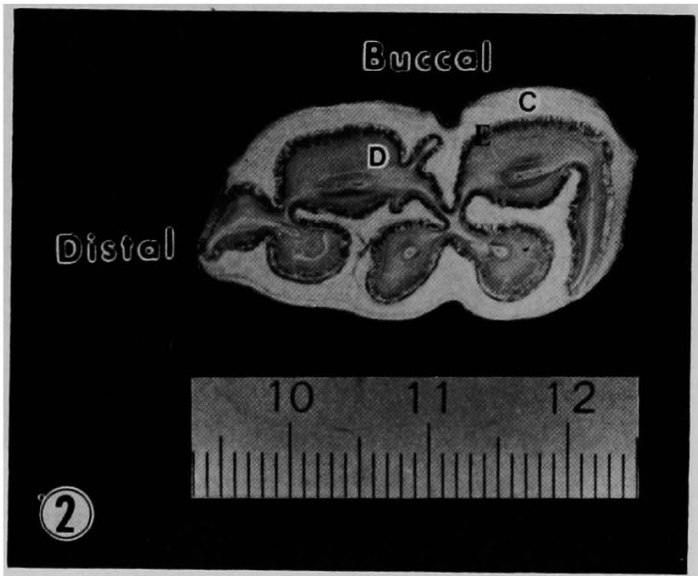

Fig. 2 Cross-sectional views of the forming crown of a horse mandibular first molar. C: Cementum, D: Dentin, E: Enamel

there was a very complex and deep invagination from the lingual surface (Fig. 2). The thickness of the cementum was increased in parallel to the enamel surface from the apical side toward the occlusal surface. In particular, the cementum had a laminar structure in the free gingiva, and was thicker toward the occlusal surface (Fig. 3-a).

1. Sharpey's fibers in coronal cementum

Sharpey's fibers were embedded in coronal cementum. The diameter of these fibers at their insertion into cementum was about 50 $\mu \mathrm{m}$ (Fig. 3-a).

Cross sections of the central portion of the anatomical crown showed Sharpey's fibers with a diameter of $20-25 \mu \mathrm{m}$ in the deep layer and surrounding mineralized cementum. The di- 


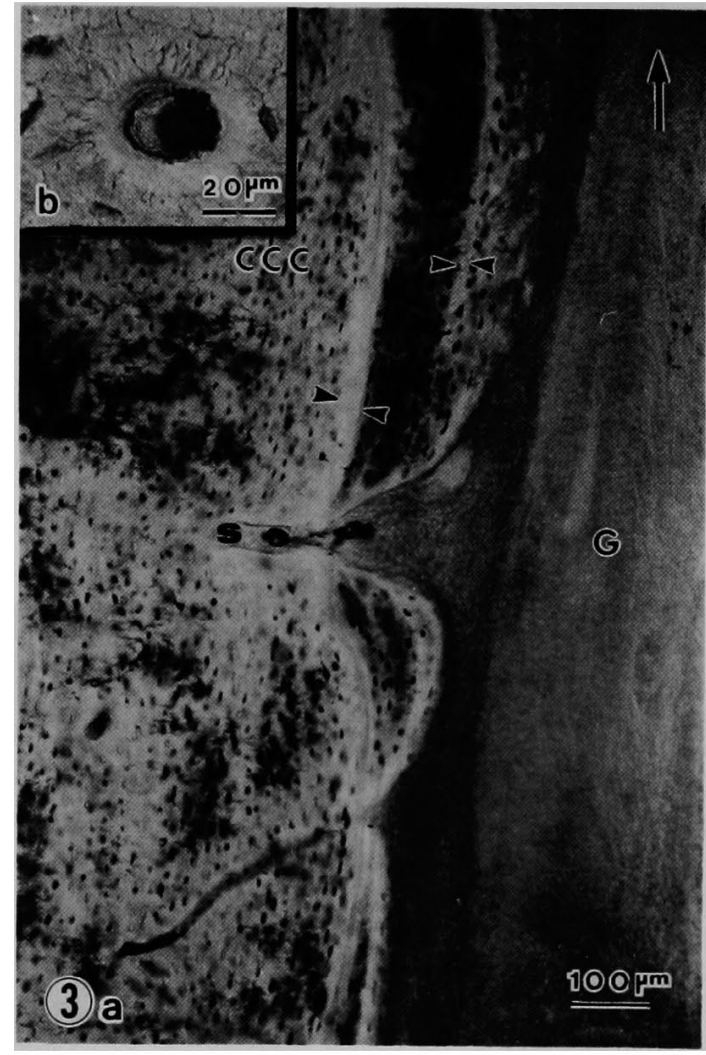

Fig. 3 Sharpey's fibers in coronal cementum. a: Fibers of periodontal ligament continue into the surface layer of the cementum as Sharpey's fibers (S). Incremental lines (between arrowheads) in cervical coronal cementum (ccc) formed by deposition of lamellae cementum on lingual gaingival wall (G). Arrow points occlusally.

b: Cross section of the deep layer in coronal cementum. Peripheral portion of Sharpey's fiber is more mineralized than their center.

ameter of the fibers including this mineralized zone was about $50 \mu \mathrm{m}$, which was similar to the diameter of fibers observed in the gingival margin (Fig. 3-b).

Contact microradiograms showed highly radiolucent Sharpey's fibers, running approximately perpendicular from the coronal cementum surface toward the cemento-enamel junction. The surface layer was seen as a newly formed and slightly less mineralized layer (Fig. 4).

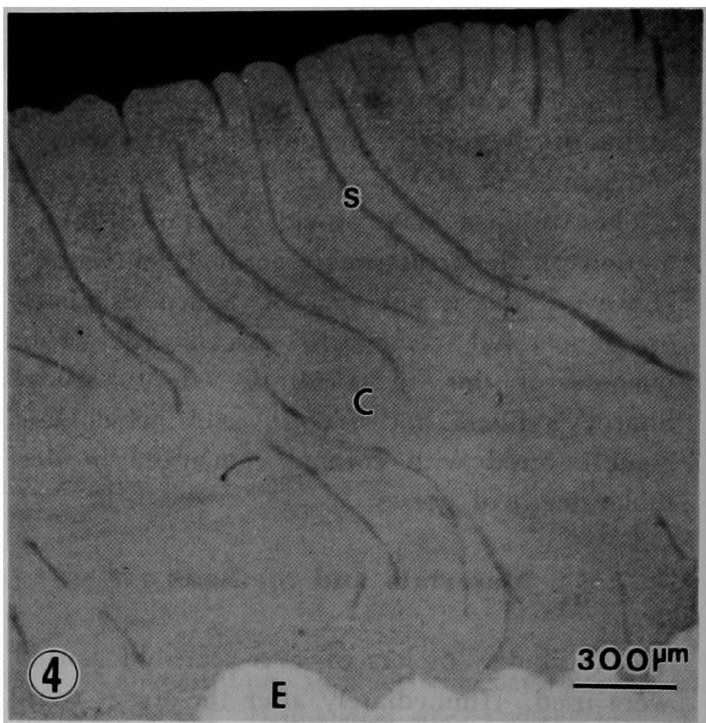

Fig. 4 Contact microradiograph of cross-section of an undecalcified mandibular molar tooth sectioned through the buccal surface of the crown.

S: Shapey's fibers, C: Cementum, E: Enamel

Regarding the surface morphology of coronal cementum near the cuspal apex, insertion sites of Sharpey's fibers that had disintegrated on the gingival margin at the time of eruption were observed as low rounded depressions (Fig. 5-a).

The fractured specimens showed the insertion of Sharpey's fibers into the coronal cementum. These fibers were aggregates of many microfibrils and had many surface processes that entered the cementum directly (Fig. 5-b).

2. Blood vessels in coronal cementum

Coronal cementum was well vascularized (Fig. 6). The concave portion of the crown was especially rich in blood vessels (30-50 $\mu \mathrm{m}$ in diamter), along their way they gave off numerous branches in the coronal cementum, which were sinusoid-like at the cemento-enamel junction (Fig. 6, 7-a).

The cemento-enamel junction was scalloped. The depressions on the enamel surface were frequently $20-50 \mu \mathrm{m}$ wide and were filled with cementum; generally there was one cementocyte per depression (Fig. 7-b).

Fractured specimens of the deep layer of cementum had many blood vessels, which were 


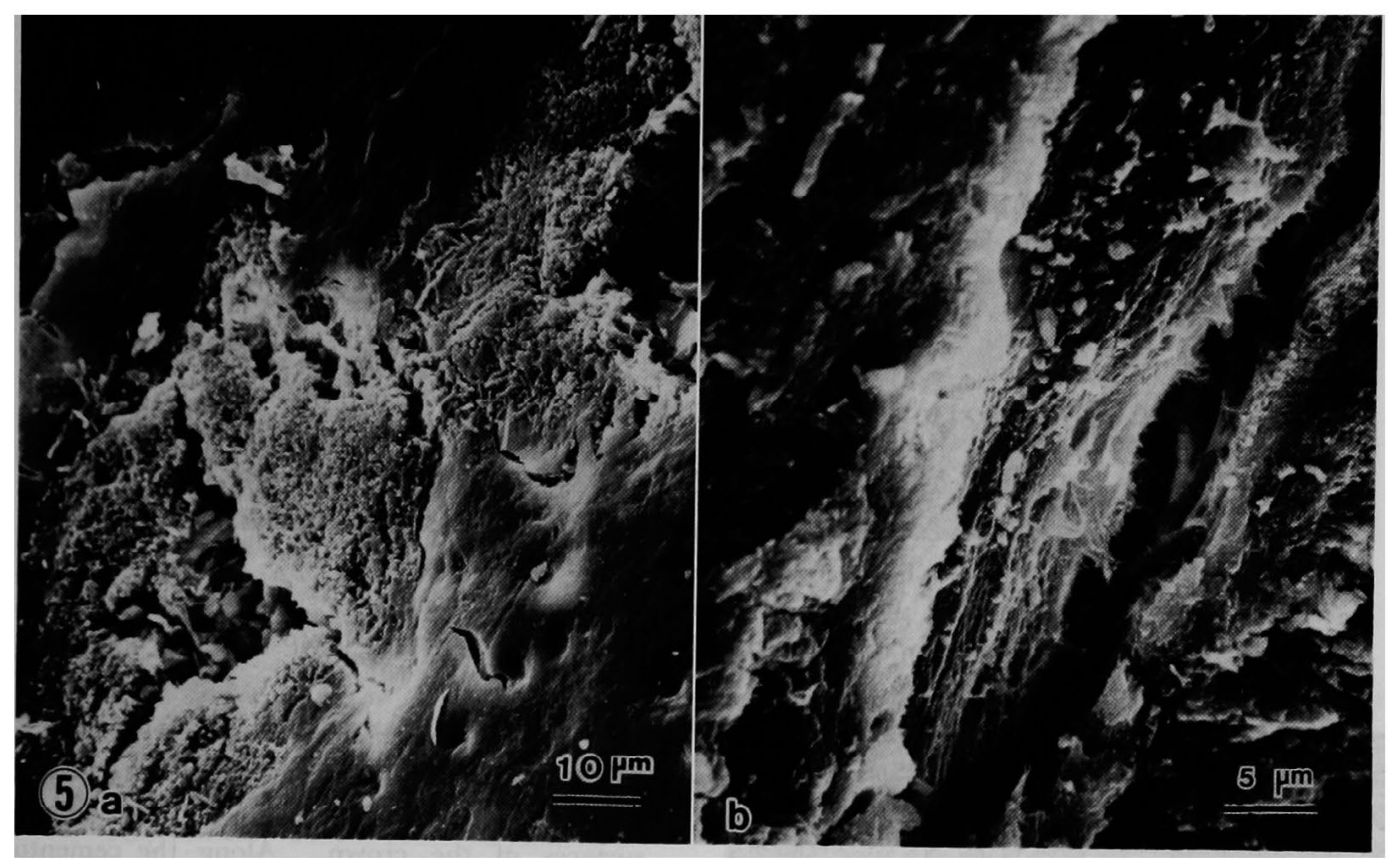

Fig. 5 Scanning electron micrograph of Sharpey's fibers.

a: Sharpey's fibers in the coronal cement surface are unmineralized

b: Cemento-enamel junction of coronal cementum illustrating Sharpey's fibers

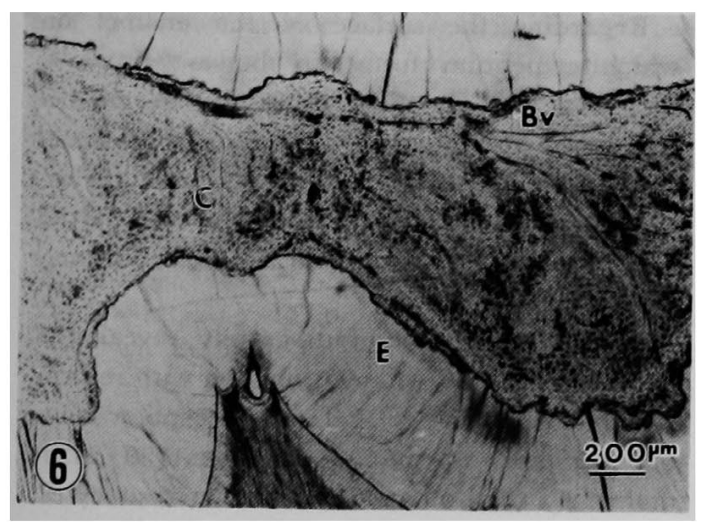

Fig. 6 The coronal cementum is extensively vascularized. Along their course in the coronal cementum blood vessels give off numerous branches.

Bv: Blood vessels, C: Coronal cementum, E: Enamel

frequently fenestrated (Fig. 8-a). In coronal cementum, the collagen fibers were often arranged circularly around the blood vessels (Fig. 8-b).

\section{Discussion}

Mastication differs among mammalian species. The primary movement of the mandible in herbivores is horizontal rather than vertical, and attrition and abrasion of the occlusal surface is marked. Corresponding to this movement, there is thick cementum on the crown in horses while the root apex is open, which allows growth over a long period. In association with this, coronal cementum is actively formed at the free gingival margins and proliferates in a laminar pattern on the cuspal apex side.

Muraki ${ }^{5)}$ reported marked proliferation of Sharpey's fibers in cementum surrounding the crown, including the portion outside the jaw. Sharpey's fibers were arranged from the surface of the coronal cementum obliquely upward to the cemento-enamel junction on the side of the cuspal apex. These findings suggested that Sharpey's fibers disconnect while being pulled in the direction of tooth eruption.

We found that many Sharpey's fibers were exposed at the surface of the coronal cementum 


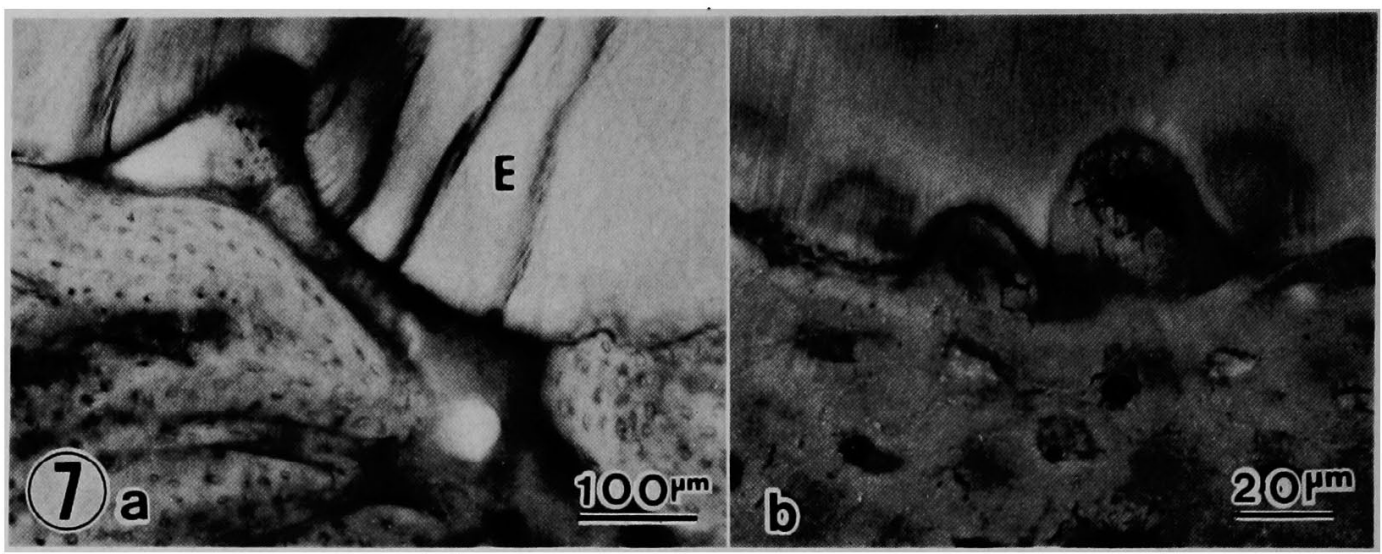

Fig. 7 Morphology of the cemento-enamel junction.

a: Blood vessel is sinusoid-like at the cemento-enamel junction. E: Enamel

b: The cemento-enamel junction was scalloped. Generally there was one cementocyte per depression

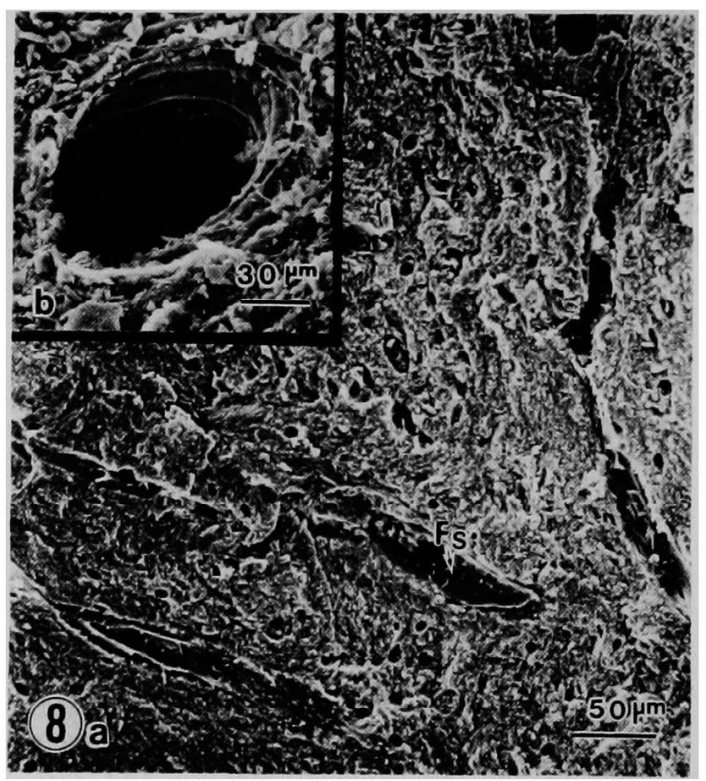

Fig. 8 Scanning electron micrograph of blood vessels in coronal cementum.

a: Deep layer of coronal cementum showing arrangement of blood vessels. Fs: Fenestrated sinusoids

b: Cross section through blood vessel. The collagen fibers are arranged circularly around blood vessels

(Fig. 5-a). This was not consistently observed in the layer from the surface to the cementoenamel junction; there were unmineralized microfibrils near areas of enamel where ce- mentum had invaginated at an early stage.

The vasculr system was well developed in the concave portion of the buccal and lingual surfaces of the crown. Along the cementoenamel junction relatively large vessels had entered the concave region, and there were sinusoid-like vessels on a part of the enamel surface (Fig. 7-a).

Regarding the surface of the enamel on which cementum forms in horses, Kawai ${ }^{18}$ ) suggested that hemispherical pits in enamel strengthen the binding of coronal cementum to the enamel surface. Using scanning electron microscopy, Jones et al.13) observed partial resorption on the enamel surface before formation of cementum.

In this study, microradiography revealed a scalloped cemento-enamel junction with resorption lacunae (Fig. 4). These resorption lacunae consisted of many small pits $(20 \mu \mathrm{m}$ in diameter) that often contained cementocytes. We evaluated the structure of Sharpey's fibers and blood vessels in coronal cementum of horse mandibular molars, by light and scanning electron microscopy. In coronal cementum, there were many Sharpey's fibers in the entire layer from the surface to the cemento-enamel junction, and mineralization had occurred from the circumferential portion. There were sinusoid-like blood vessels at the cemento-enamel junction, with a diameter of $30-50 \mu \mathrm{m}$. Along their way they gave off numerous branches in the coronal cementum. 


\section{Acknowledgment}

This study was supported in part by the
Japanese Ministry of Education (1988, 1989), Science and Culture under a Grant-in-Aid For Scientific Research (63570850).

抄録 : 本研究はウマの歯冠セメント質の構造的特徵を検索したものである。特に歯冠セメント質内の膠原 線維束 (シャーピー線維) の構造と配列そして血管分布, さらにセメントエナメル境の形態について屠殺直

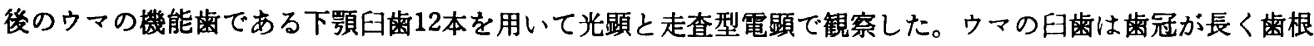
は短い高位歯で長期にわたって萌出し，歯冠セメント質の形成は歯肉縁付近で盛んで周期的な層構造をなし ていた。シャーピー線維は歯冠セメント質表面で直径が約 $50 \mu \mathrm{m}$ で深層では周囲が石灰化して直径が約 20 〜25 $\mu \mathrm{m}$ のものがみられた。血管系は歯冠頓舌面の陥凹で発達して拈り，セメントエナメル境に沿って比較 的太い血管が進入し, 経過の途中で多くの枝を出し, セメントェナメル境部で静脈洞様を呈していた。セメ ントエナメル境は波状面を呈し, 吸収された窪みとなったエナメル質表面に歯冠セメント質が強固に接着し ていた。

\section{References}

1) Fujita, T. : Dental histology, 9 th ed, pp. 133 -146, M.D.P., Tokyo, 1968. (in Japanese)

2) Havers, C. : Osteologia Nova or Some New Observation of the Bones ( 5 th discourse on bones and teeth to the Royal Society). London, 1961, Smith.

3) Owen, R. : Odontography; or a treatise on the comparative anatomy of the teeth; Their physiological relations, mode of development, and microscopic structure, in the vertebrate animals. London, 1840-1845, Hippolyte Bailliere Pub., Vol. I, II.

4) Brunn, A.V.: Beiträge zur Kenntiniss der Zahnentwicklung. Arch. mikr. Anat. 38 : 142 $-156,1891$.

5) Muraki, Y. : Comparative-Anatomical studies on the cementum of the mammalian teeth. Acta Anat. Nippon. $33: 583-611$, 1958. (in Japanese)

6) Boyde, A. and Jones, S. J. : Scanning electron microscopy of cementum and sharpy fiber bone. Zschr. f. Zellf. 92 : 536-548, 1969.

7) Glimcher, M.J., Friberg, U.A. and Levine, P.T. : The identification and characterization of a calcified layer of coronal cementum in erupted bovine teeth. J. Ultrastruct. Res. 25 : 891-908, 1964.

8) Mills, P.B. and Irving, J.T. : Coronal cementogenesis in cattle. Archs Oral Biol. $12: 929$ 932, 1967.
9) Listgarten, M.A. : A light and electron microscopic study of coronal cementogenesis. Archs Oral Biol. 13 : 93-114, 1968.

10) Ainamo, J. : Morphogenetic and functional characteristics of coronal cementum in bovine molars. Scand. J. Dent. Res. 78 : 378-386, 1970.

11) Gottlieb, B. : Biology of the cementum. J. Periodont. 13 : 3-17, 1942.

12) Weinreb, M.M. and Sharav, Y. : Tooth development in sheep. Am. J. Vet. Res. 25 : 891-908, 1964.

13) Jones, S.J. and Boyde, A. : Coronal cementogenesis in the horse. Arch. Oral Biol. 19 : 605-614, 1974.

14) Longmore, B. : Coronal cementum in the rabbit, guinea pig and the horse. J. Dent. Res. 47 : 997-998, 1969.

15) Gottlieb, B. and Griener, E. : Der histologische Bau der Meerschweinchenmolaren und ihres Befestigungsapparates. I. Teil. Der histologische Bau der Meerschweinchenmolaren. Z. Stomat. 21 : 565-580, 1923.

16) Hunt, A.M. : A description of the molar teeth and investing tissues of normal guinea pigs. J. Dent. Res. 38 : 216-231, 1959.

17) Tanaka, S. : Histogenetic studies on the cementum pearls in guinea-pig molars. J. Stomatol. Soc. Jan. $47: 281-328$, 1980. (in Japanese)

18) Kawai, N. : Comparative anatomy of the bands of Schreger. Okajimas Fol. Anat. Jap. 27 : 115-131, 1955. 